\title{
Investigating The Effectiveness of Critical Literacy Approach in Developing EFL students Critical Reading Skills
}

\section{AL-Shaimaa Abdullah El-Maghraby}

Lecturer in Faculty of Foreign Languages and

Translation (English Department) Misr

University for Science and Technology (MUST) 



\section{Abstract:}

The present study aimed at enhancing EFL learner's critical reading skills using critical literacy. The study used the quasiexperimental method. The participants were a group of 56 students are second-year English majors at Misr University of Science and Technology (MUST). The researcher's students during the first semester of the academic year 2020-2021. Students of one class (28 students) were treated as the experimental group and the other played the role of the control group (28 students) who were chosen to implement the research experiment. Results revealed that there is a statistically significant difference between the mean score of the experimental group students and those of the control group of post-test in favor of the experimental group. This indicates that the literacy approach that occurred in the experimental group had a significant effect on EFL students' critical reading skills.

Keywords: Critical Literacy, Critical Reading, EFL Reading Skills

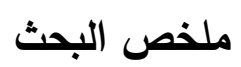

تهدف الدراسه الحاليه الى تتميه مهاره القراءه الناقده لدى دارسى اللغه الإنجليزيه كلغه

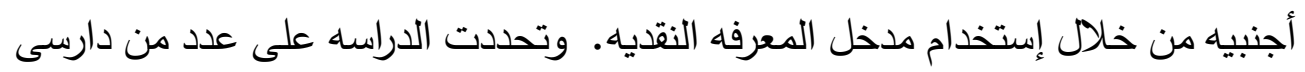
اللغه الانجليزيه كلغه اجنبيه ( ست وخمسون طالب من طلاب الفرقه الثانيه بقسم اللغه الإنجليزيه بكليه اللغات والترجمه بجامعه مصر للعلوم والتكنولوجيا فى الفصل الدراسى 
الأول للعام الأكاديمى 2020-2021. تم تطبيق مدخل المعرفه النقديه على 28 طالب (مجموعه تجريبيه) و 28 طالب كمجموعه ضابطه وبعد الإنتهاء من التجربه وتطبيق

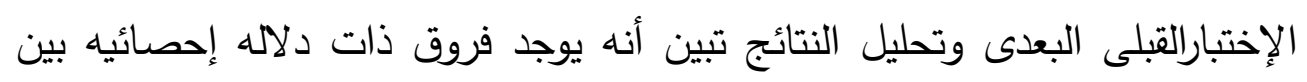
متوسط درجات عينه البحث فى التطبيقين القبلى والبعدى لصاح التطبيق البعدى. ومن التبن

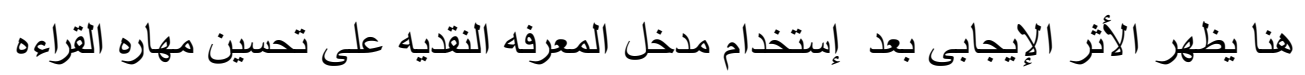

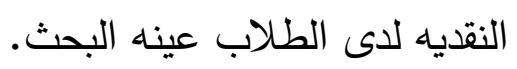
كلمات مفتاحيه : مدخل المعرفه النقديه - القراءه النقديه - مهارات القراءه لدارسى اللغه الإنجليزيه كلغه أجنبيه .

\section{Introduction}

Critical reading skills play an important role in language learning classes. Language learners read the texts in order not only to grasp unfamiliar terms or the context of the entire sentence, but also to go beyond the sentences, that is, to get the intended meanings of the authors. However, every passage definitely has secret ideas and messages that should not be neglected. In order to consider this matter, Schooten and Glopper (2003, p.160) state that the emphasis of several studies has shifted from the author of the text to the reader or the relationship between the reader and the text. Improving the ability of students to reason requires "seeking knowledge that is not explicitly specified in the passage" (Peterson's, 2008, p. 124). 
In English as a foreign language (EFL) classrooms, reading exercises commonly include finding new words, reading relevant texts, finding answers to multiple-choice questions, true/false statements, or short discussions about reading choices. Beyond these practices, it is seldom to expand to other standards or to study critical reading in EFL books.

Critical reading originates from the idea of critical thinking. It is the application of critical thinking to the reading process. Highered (2010) points out that critical reading ensures that readers consider while they read. In addition, He describes that being critical means responding to the text and the writer, blatantly disregarding or accepting the statements of the writer, asking questions, and adapting what we read to what we know and believe. Highered's (2010) opinion on critical reading is close to Kurland's (2011) opinion, which describes it as a technique for discovering knowledge and ideas inside a text. Whereas critical thinking is a method for analyzing that knowledge and ideas, for deciding what to accept and believe. To sum up, critical reading refers to the critical thinking that is applied to the reading and writing process (Chaffee, 2000, PP.55-63; Reichenbach, 2001). 
Critical reading skills are particularly important for university students. These skills are required not only for learning, but also for everyday life. Unfortunately, their skills are not sufficient to meet the challenge they face. As one of the English skills, reading plays an important role for the majority of university students, not only in the understanding of the materials provided by the lecturers, but also in the comprehension of any texts they can find in their everyday lives. Being a successful reader is going to give the graduates the upper hand. Having English skills and the ability to read critically would give students the opportunity to succeed in a competitive world.

Students who take reading lessons are believed to have advanced reading skills as they are at the university level. In fact, during the two semesters the researcher taught reading subjects, it seems like their reading skills are still poor. It can be seen from the classroom activities that require positive participation of the students. The students' response to the text is mostly very slow, and they have less effort and engagement when pdealing with more complicated reading tasks. It's because students just read the surface or find information from the text that doesn't attempt to interpret or understand what beyond the text. So, whenever students don't get the answers or the solutions, they'll get the answers, they will stop reading. In the context of such a 
difficult situation, the researcher aims to familiarize students with reading activities that required more critical and logical thinking skills that are critical to reading.

Critical reading refers to active, reflective and analytical reading. Critical reading was described as learning to analyze, draw inferences and come to conclusions based on facts (Zintz and Maggart in Tabrizi, 2011). One approach that encourages critical reading is the use of the class's authentic texts. Authentic texts such as newspapers, magazines, television and radio can encourage students to learn critical listening and reading skills. Students' critical reading practices need devotion to more active or positive readings and interaction with the text they read.

Critical reading is a dynamic thought technique that includes the discovery and identification of the author's meaning, the evaluation of the author's meanings on the basis of established criteria, and the integration of meaning into the ideas that readers already know (Kurt-Taşpınar\& Çubukçu, 2020, p.42.). Critical reading goes beyond basic comprehension and requires to grasp the ideas of the author, even if they are not explicitly mentioned.

- Identifying organizational patterns in what you read

- Using a questioning strategy before, during, and after reading. 
Developing EFL student's Critical Reading Skills Dr. AL-Shaimaa Abdullah

- Prioritizing the thoughts of the author

- Defining and testing the claims of the author

- Developing new concepts using the ideas of the author

EFL educators have been searching for several ways to improve essential reading skills. Critical literacy has recently become a key component of higher education in particular, as learners are exposed to an instant and complex flow of information through computer technologies and the Internet. $T$ herefore, it is obligatory that learners become critically literate by developing their high-level thinking skills and problem-solving skills and exploring different perspectives (Fajardo, 2015, p.3537). Improving the critical consciousness of learners is crucial (Callison, 2006) because the primary purpose of education is "learning to think" (Dewey, 1933; as cited in Halpern, 1997, p. 5).

Critical literacy is a crucial skill in today's world, especially in the field of language and literacy (Brown, 1999). Wallace (2003) argues that "understanding the text linguistically and conceptually must be an initial step for all reading positions, but readers may want and need to respond to the texts in a more diverse and comprehensive way than is commonly recognized. Both learners, whether they read in the first, second or other language, are, from the earliest stages, theoretically both making sense from the texts and engaging in criticism" (p. 3). Thus, there should be more 
concentration on the linguistic and conceptual dimensions of text and literacy education in the 21st century.

The basic terms of critical literacy rely on the two words explained by the authors; critical stance and critical edge. Critical stance is used when students use their prior knowledge to understand the power relationship between their ideas and the ideas provided by the authors' subject, and when they read, students exercise that power. Critical edge means "going beyond comprehension of the text in order to understand the power dynamics that exist between the reader and the author;" thus, readers need to become active participants and text critics in order to know the power relationship (Mclaughlin and Devoogd, p.21)

Tony Gurr shows the main functions of critical literacy in figure 1 ("Emotional Literacy"). He explains how critical literacy is closely linked to our systems of thought and mind. Critical literacy links all literacy that operates in our brains: analysis, evaluation, synthesis, problem solving, self-direction and so on. Cognitive actions of students regarding these abilities are needed to improve essential literacy skills. Critical literacy education thus helps learners use language to examine language and power 
Developing EFL student's Critical Reading Skills Dr. AL-Shaimaa Abdullah

relationships in the social practices they encounter. Anstey and Bull (2006) illustrate the dangers that learners would face if they are not taught to read critically because "they can be excluded, discriminated against, or unable to take an active position in life.

In short, the student would not be in charge of his or her social future' (p. 31, as cited in Kaur, 2013). Reading critically allows individuals to become involved and educated people as a prerequisite for the development of new literacies in today's digital age and the changing literacy needs of learners.

Figure 1: Critical Literc

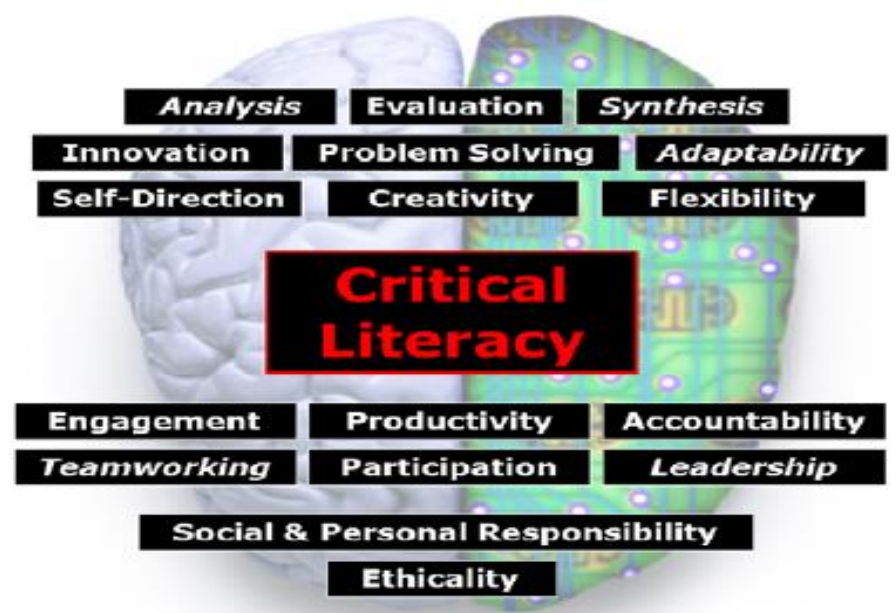

Jeong (2012, p.18)

In order to read critically, every learner have to think critically to. This includes analysis, comprehension and interpretation, and evaluation. Each of these processes helps you interact with the 
text in a variety of ways: highlighting main points and examples, taking notes, checking answers to your questions, brainstorming, outlining, explaining aspects of the text or argument, reflecting on your own reading and thought, raising objections to the ideas or evidence given, etc.

\section{Statement of the problem}

In Egypt, the change to the digital era has contributed to the need for human capital that have the capacity to think critically. In the context of English Language Teaching (ELT), which has contributed to the growth of language skills, critical thinking and critical literacy, there is a real need to teach English that is important to the current situation in Egypt. Therefore, alternative ways of teaching reading that will produce critical readers are required. Moreover, in the Egyptian EFL context, eading is meant for comprehension, i.e. to reassert the opinion of the writer rather than reading against the text and its ideology, which is another part of the issue that contributes to inability to comprehend. With the lack of critical reading skills amongst undergraduate EFL students, the current study attempts to apply critical literacy approach to enhance EFL studentss' critical reading skills. 


\section{Research Questions:}

To achieve the purpose of this research, the following questions are addressed:

What is the effect of Critical Literacy Approach on the EFL students' Critical reading skills?

-What is the effect of Critical Literacy Approach on the EFL students'comprehension and interpretation skills?

-What is the effect of Critical Literacy Approach on the EFL students'analysis skills?

-What is the effect of Critical Literacy Approach on the EFL students' evaluation skills?

-What is the effect of Critical Literacy Approach on the EFL students' Synthesis skills?

\section{Research Hypotheses:}

1. There is a statistically significant difference between the mean score of the experimental group students and those of the control group in the Critical reading skills of post-test in favor of the experimental group students.

1.1. There is a statistically significant difference between the mean score of the experimental group students and that of the control group in the Comprehensison and interpretation skills of post-test in favor of the experimental group students. 
1.2. There is a statistically significant difference between the mean score of the experimental group students and that of the control group in the Analysis skills of post-test in favor of the experimental group students.

1.3. There is a statistically significant difference between the mean score of the experimental group students and that of the control group in the Evaluation skills of post-test in favor of the experimental group students.

1.4. There is a statistically significant difference between the mean score of the experimental group students and that of the control group in the synthesis skills of post-test in favor of the experimental group students.

\section{Definition of terms:}

This research has two operational definitions of variable are:

\subsection{Critical literacy}

Dionne (2010) describes critical literacy as "a lens or overlay for viewing texts that become a daily part of classroom practice"( $p$. 3). For Janks (2013),"critical literacy is primarily about empowering young people to read both the word and the world in terms of influence, identity, disparity and availability of information, skills, tools and resources. It's also about writing and rewriting the 
world: it's about design and re-design" (p. 227). Operationally, the researcher used it as a method that goes beyond memorizing and recognizing the degree of criticism and creating a parallel text focused on a critical stance.

\subsection{Critical reading}

Critical reading was described as learning to analyze, draw inferences and come to conclusions backed by evidence (Zintz, M. V., and Z. R. Maggart in Tabrizi, 2011). It is closely related to critical thinking; in both ways, a student needs to learn various methods for identifying concepts, interpreting ideas, and examining texts as a prerequisite for understanding controversial ideas, demonstrating his/her point of view, as well as challenging other ideas and formulating a new claim. Operationally, the researcher used it as a realistic method that uses the theoretical concept of critical literacy as a theory that, according to Nava, is often referred to as a political act that rotates around questioning, analyzing and dismantling the given non-questionable status introduced in the text. (Ramirez-Nava, 2013).

\section{Theoretical background}

Various research has been undertaken exploring the efficacy of critical literacy activities in EFL/ESL teaching. Pesarchick (2018) investigated the critical literacy activities employed by 5th grade teachers while teaching reading. This research was aimed 
at studying the critical literacy practices of teachers after learning and refining critical literacy practices. In addition, the research discussed how self-efficacy of teachers has had an influence on the implementation of innovative concepts. The results of this study emphasized the role of teachers in developing critical literacy activities, which are deemed necessary for teachers to increase the in-depth text review provided at critical literacy sessions.

Weissman (2018) identified the attitudes and expectations of some pre-school teachers who used critical literacy in their classrooms, using existing themes common to childhood literature. The research is a case study that is focused on data collection interviews. Weissman argues that the research provides an account of how critical literacy can be established.

Nam, (2013) focused on the challenges of helping students produce critical responses to ESL reading textbooks with a view to investigating the possibility of using the concepts of critical literacy in English as a second-language classroom when adapting their practices to ESL reading text. Nam concluded that the research participants were engaged in critical literacy practices and were able to disturb the common place, consider 
multiple viewpoints, and focus on the sociopolitical aspects of the text in many ways. In other studies, (e.g., Abednia \& Izadinia, 2013, p.340; Cho, 2014; Dal, 2012; Potur, 2014), some critical literacy applications have been integrated into the teaching process and the effect of intervention has been established. In some other studies (e.g., Huang, 2011; Huh, 2016), researchers concentrate on the combined teaching of traditional and critical literacy skills in a balanced way and critical language analysis to improve critical literacy.

On the other hand, ESL/EFL practitioners claimed that the way to teach students to be critical readers is when the text is addressed in different dimentions. A research by Haromi (2014) on the impact of teaching on critical reading students through assessment. The research shows the positive effects of the technique on students with critical reading skills.

Critical reading can be recognized on the basis of several characteristics as demonstrated by Huljiue (2010) in his research. The reader begins by evaluating the claims made, the strength and weakness of the text and then discusses the facts supporting the authors' opinion and eventually examines whether the authors' point of view is supported or rejected.

Quesioning the teaching and learning process plays a vital role in educating essential reading students. A case study of 
teacher experience in critical reading instruction, researcher Ko (2013) identified critical questions and a critical discussion with students helped a lot in improving critical reading skills. It highlighted the difficulties of implementing a literacy approach in classrooms for a variety of reasons, such as student language learning beleifs and teaching resorces.

Duran\& Yalçintaş's (2014) research was conducted to determine the ability of fourth-grade primary children to learn critical reading skills; the teacher's response to the evaluation of student critical reading skills was also assessed. Results have shown that children are able to develop essential reading skills despite their age. Teachers, however, need to develop the resources with which to evaluate the skills learned by their students. Moreover, Escudero (2011) in his research analyzed the implementation of the critical reading remedial program in one of Mexico's universities and its effect on Mexican EFL students' readings. Results have shown that reading the reading tasks with important reading questions has a statistically significant effect on students' ability to think critically and to read critically too.

The above mentioned studies revealed several findings lead us to the conclusion that a critical reading method can develop 
learner into a critical reader. Kress (2003) \& Kustini (2010) argues that in the field of language studies, advocates of critical theory would like learners to be more engaged and critical in trying to make sense of the text rather than passively absorbing the text. In the same context, Wallace (2003) argues that, from a critical reading point of view, the reader actively pursues the meaning of the text, as opposed to the ealier concept that reading is generally classified as passive ability. Readers do not support the point of view of the text in silence, rather they evaluate the reasons why the author develops it and then begin to determine its credibility.

\section{Method}

\section{Research Designe}

\subsection{Instruments and Materials}

1. A Critical Reading text pre-post-test, (Appendix 1)

2. A Critical reading texts rubric (Appendix 2)

3. A Critical Reading Guidlines (Appendix 3)

7.1.1 Reliability and Validity of the EFL Critical Reading Test

Test validity was measured using content validity by expert judgment. The test, which was developed, was examined by two reading experts. Experts were asked to correct each test item and to assess the important reading aspects of the test. The test was then attempted to test its reliability. Cronbach's alpha internal 
quality coefficients were 0.645 for comprehension and understanding skills 0.896 for reasoning skills, and 0.712 for assessment skills. The alpha coefficient of Cronbach for all vital reading skills was 0.882 .

\subsection{Participants}

Two classes of 56 students are Second-year English majors at Misr University of Science and Technology (MUST). (the researcher's students during the first semester of the academic year 2020-2021.) Students of One class (28 students) was treated as the experimental group and the other played the role of the control group (28 students), they were chosen to implement the research experiment. The groups were assigned randomly since they were considered to have the same characteristics. The sample groups were all enrolled in the first semester of an undergraduate program. eighty percent of the sample was female. These students' English proficiency was expected at upper intermediate level or B2 according to Common European Framework of Reference.

\section{Research Procedures}

A set of training materials was developed through a variety of activities: (1) competence development, sub-competence and 
indicators, (2) text collection, (3) text readability and attractiveness checking, and (4) promotion of reading activities. Texts have been chosen as they could pose problems for students to solve, have cross-cultural material and texts that could give students alternative discourses. As Wallace (2003) mentioned in his book, the reading activites were devided into three phases: the pre-reading phase, while reading phase, and post reading phase.

Table 1: Phases of Teaching Critical Reading

\begin{tabular}{|c|c|c|}
\hline & & $\begin{array}{l}\text { Post-reading } \\
\text { activities: }\end{array}$ \\
\hline $\begin{array}{l}\text { In this phase, } \\
\text { instructors should } \\
\text { allow students to } \\
\text { come up with their } \\
\text { own concerns, } \\
\text { statements or } \\
\text { assumptions rather } \\
\text { than answer questions } \\
\text { that determine a way } \\
\text { of reading the texts. In } \\
\text { this so-called critical } \\
\text { approach to reading, } \\
\text { students are required } \\
\text { to pose more }\end{array}$ & $\begin{array}{l}\text { At this phase, } \\
\text { instructors may offer } \\
\text { students alternative } \\
\text { readings of the text. } \\
\text { Students should be } \\
\text { encouraged to think } \\
\text { critically about the } \\
\text { various discourses that } \\
\text { could be obtained from } \\
\text { the text. They should } \\
\text { be taught that there is } \\
\text { not only one discourse } \\
\text { that can be found in } \\
\text { the text, but that there }\end{array}$ & $\begin{array}{l}\text { In this phase, teachers } \\
\text { could carry out } \\
\text { exercises that would } \\
\text { enable students to think } \\
\text { critically about other } \\
\text { ways in which the topic } \\
\text { of the reading text } \\
\text { could have been } \\
\text { written. The use of two } \\
\text { texts dealing with the } \\
\text { same subject, but } \\
\text { drawing on different } \\
\text { discourses and } \\
\text { suggesting a different }\end{array}$ \\
\hline
\end{tabular}




\begin{tabular}{|l|l|l|}
\hline \hline questions in the & is more than one. & model reader, may be \\
course of reading. & Instructors need to be & used in this operation. \\
This is very different & imaginative enough to & Teachers can ask \\
from the traditional & figure out reading & students to identify the \\
reading task, where & tasks that might give & different features of the \\
the aim is only for & students the & two texts (two stories \\
students to find & opportunity to read the & can be use here). \\
answers. & text in several ways. & \\
\hline
\end{tabular}

Wallace (2003) Critical Reading in Language Education.

Lee's Summit, Missouri; (2000) states that the following critical reading techniques (can be studied and applied to all college readings) and mastering them will help one deal with difficult material with confidence: annotating, previewing, contextualizing, questioning, reflecting, outlining, summarizing, evaluating an argument and finally comparing and contrasting related readings.

Critical thinking while reading is vital to academic performance, because a lot of people writing tasks would require critical analysis of the work of others. It is the ability to think, analyze, interpret and evaluate texts; yet this whole complicated process starts with basic scepticism, which usually refers to assumptions and cultural stereotypes. Only then can they succeed in teaching critical to their students as educators. 
Cotterall (1990) suggests that, when reading, critical thinking requires the following: Identify the line of argument in the text. Critical evaluation of the type of argument. Questioning surface appearances and searching for hidden assumptions or agendas. Identifying the evidence in the text. Evaluation of the evidence according to valid standards. Identifying the claims of the author and determining if the evidence presented supports those claims.

Critical reading skills were adapted from the Facione's critical thinking skills taxonomy $(1990,2013,2015)$ which consisted of three levels: comprehension and interpretation skills, analytical skills and evaluation skills. The reading activities carried out in this research included two types of texts: articles and editorials. The reading process included pre-reading, reading, and postreading. Reading comprehension questions have been deliberately designed to evaluate participants' ability to criticize texts. The test of critical reading consisted of 40 items. A literature review was conducted prior to the establishment of the test blueprint.

\section{Data Collection and Analysis}

Three steps of the data analysis were carried out: (1) data management; (2) statistical analysis; and (3) comprehension and interpretation of the findings. Data management involved the grouping, coding, marking and labeling of reply sheets. In order 
to ensure the objectivity of the results, two scorers analyzed the test. The data was statistically analyzed using SPSS statistics. The test results showed a significance value of 0.712 for the experimental group and 0.999 for the control group. This result indicated that the distribution of data between the experimental group and the control group was normal. The ANCOVA test was conducted to reveal the effect of the critical literacy approach on improving students' critical reading skills. The significance level determined was $\alpha=.05$. The interpretation of the results was based on the theories and findings of the related previous research. The researchers' points of view were also included.

\section{Findings and Discussions}

The pre-test and post-test mean scores of the experimental and control groups at each ability level are shown in Table (2). The table also shows the percentage of improved pre-test and posttest mean scores for each group. These findings indicate the hypothesis that there is a statistically significant difference between the mean score of the experimental group students and those of the control group of post-test in favor of the experimental group students. 
Developing EFL student's Critical Reading Skills Dr. AL-Shaimaa Abdullah

Table 2: The mean score of pretest post test of both experimental and control group.

\begin{tabular}{|c|c|c|c|c|}
\hline Groups & Skills & Post-test & Pre-test & scores \\
\hline Experemental Group & \multirow{2}{*}{$\begin{array}{l}\text { Interpretation } \\
\text { \&Comprehension }\end{array}$} & 3.46 & 6.39 & 2.93 \\
\hline Control Group & & 3.68 & 5.29 & 1.61 \\
\hline Experemental Group & \multirow{2}{*}{ Analysis } & 2.96 & 6.96 & 4 \\
\hline Control Group & & 3.25 & 3.64 & .39 \\
\hline Experemental Group & \multirow[b]{2}{*}{ Evaluation } & 6.91 & 14.43 & 7.52 \\
\hline Control Group & & 7.11 & 9.57 & 2.64 \\
\hline Experemental Group & \multirow{3}{*}{ Synthsise } & 7.15 & 14.8 & 7.90 \\
\hline & & 7.33 & 11.2 & 2.81 \\
\hline Control Group & & & & \\
\hline
\end{tabular}

The value shown in table 3 indicates that $F=1.387$ has a significance level of.242 ( $p>$.05). This suggests that no significant effect has been found on enhancing the understanding and interpretation skills of EFL students. Based on the influence of the literacy approach, it was found that $F=9.433$ had a significance level of.003. These findings verify the hypothises that there is a statistically significant difference between the mean score of the experimental group students and those of the control group in the on interpretation and comprehension skills of posttest in favor of the experimental group students Table 3: The Results of the ANCOVA Test on Interpretation and comprehension skills 


\begin{tabular}{|l|l|l|l|l|l|}
\hline Source & Sum of squres & df & Mean square & F & Sig \\
\hline Intercept & 169.122 & 1 & 169.122 & 88.135 & .009 \\
\hline pretest & 2.645 & 1 & 2.645 & 1.387 & .000 \\
\hline Literacy Approach & 18.211 & 1 & 18.211 & 9.433 & .003 \\
\hline Total & 121.554 & 55 & \multicolumn{3}{|l}{} \\
\hline
\end{tabular}

The value shown in table 4 reveals that $F=.887$ has a significance level of.351 ( $p>.05)$. This suggests that no important impact has been found on improving the skills of EFL students in analysis. Due to the influence of the literacy approach, it was found that $F=65,201$ had a significance level of 5,000. These findings verify the hypothises that there is a statistically significant difference between the mean score of the experimental group students and those of the control group in the on analysis skills of post-test in favor of the experimental group students.

Table 4: The Results of the ANCOVA Test on Analysis skills

\begin{tabular}{|l|l|l|l|l|l|}
\hline Source & Sum of squres & df & Mean square & F & Sig \\
\hline Intercept & 202.172 & 1 & 202.172 & 84.604 & .000 \\
\hline pretest & 2.130 & 1 & 2.130 & .887 & .351 \\
\hline Literacy Approach & 156.563 & 1 & 156.563 & 65.202 & .000 \\
& & & & & \\
\hline Total & 283.839 & 55 & \multicolumn{3}{|l}{} \\
\hline
\end{tabular}

The value shown in table 5 indicates that $F=1,943$ has a significance level of.169 ( $p>.05)$. This indicates that there has been no significant effect on the evaluation skills of the EFL 
students. Based on the literacy approach, it was found that $\mathrm{F}=38,589$ had a degree of significance of 5,000. These findings verify the hypotheses that there is a statistically significant difference between the mean score of the experimental group students and those of the control group in the the evaluation skills of post-test in favor of the experimental group students.

Table 5: The Results of the ANCOVA Test on Evaluation skills

\begin{tabular}{|l|l|l|l|l|l|}
\hline Source & $\begin{array}{l}\text { Sum } \\
\text { squres }\end{array}$ & df & $\begin{array}{l}\text { Mean } \\
\text { square }\end{array}$ & F & Sig \\
\hline Intercept & 432.302 & 1 & 432.302 & 56.508 & .000 \\
\hline pretest & 14.856 & 1 & 14.856 & 1.943 & .169 \\
\hline $\begin{array}{l}\text { Literacy } \\
\text { Approach }\end{array}$ & 295.060 & 1 & 295.060 & 38.589 & .000 \\
\hline Total & 726.554 & 55 & \multicolumn{3}{|l|}{} \\
\hline
\end{tabular}

The value shown in table 6 indicates that $F=0,82$ has a significance level of .776 $(p>.05)$. This indicates that there has been no significant effect on the evaluation skills of the EFL students. Based on the literacy approach, it was found that $F=81.789$ had a degree of significance of 0.000 . These findings verify the hypotheses that there is a statistically significant difference between the mean score of the experimental group students and those of the control group in the synthesis skills of post-test in favor of the experimental group students.

Table 6: The Results of the ANCOVA Test on synthesis Skills 


\begin{tabular}{|l|l|l|l|l|l|}
\hline \hline Source & Sum of squres & df & $\begin{array}{l}\text { Mean } \\
\text { square }\end{array}$ & F & Sig \\
\hline Intercept & 192.69 & 1 & 192.69 & $\mathbf{5 6 . 5 0 8}$ & $\mathbf{. 0 0 0}$ \\
\hline pretest & .349 & 1 & .349 & $\mathbf{0 . 8 2}$ & .776 \\
\hline $\begin{array}{l}\text { Literacy } \\
\text { Approach }\end{array}$ & $\mathbf{3 3 9 . 4 0 3}$ & 1 & $\mathbf{3 3 3 . 4 0 3}$ & $\mathbf{8 1 . 7 8 9}$ & .000 \\
\hline Total & $\mathbf{5 6 1 . 0 0 0}$ & $\mathbf{5 5}$ & \multicolumn{4}{|l|}{} \\
\hline
\end{tabular}

\section{Conclusion}

It can be inferred from the results of the study presented in table 2 that there was an improvement of students' achievement in critical reading skills in both classes. However, the students in the experimental group achieved better compared to the control group. This indicates that the learning process that occurred in the experimental group was more effective than the learning process that occurred in the control group. Based on the ANCOVA test, it was found that the critical literacy approach had a significant effect on comprehension and interpretation skill, analysis skill and evaluation of EFL students.

The results of this study are in line with the results of the study carried out by Içmez (2009). It was about the critical reading of English language prep courses. Essential reading activities during the lesson have been shown to improve communication among students and encouragement for reading lessons.Furthermore, the findings of the present study confirm the 
results of the studies conducted in different EFL contexts (Abbasian \& Malaee, 2016; Hazaea \& Alzubi, 2017; In Abbasian and Malaees (2016) study, they investigated the impact of explicit teaching of some of the Critical Discourse Analysis (CDA) techniques on the reading comprehension of Iranian EFL learners. The findings revealed that the experimental group was advised to objectively read higher scores than the control group.

The present research also confirms the results of the Hazaea and Alzubi (2017) study conducted in the Saudi Arabian tertiary context to explore the effect of CDA instruction on EFL analytical reading practices as well since the results of this study indicated significant effects on the analytical practices (i.e., description, interpretation and explanation). For the above mentioned results it is better for EFL practioners to implement both critical literacy and conventional approach to overcome the problems that slow learners face while learning critical reading skills.

\section{References}

- Abbasian, G. R., \& Malaee, N. (2015). The effect of critical discourse analysis instruction on Iranian EFL learners' reading comprehension and orientation. The Journal of Applied Linguistics, 8(17), 1-20. Retrieved 25 January 2021 from http://www.iaujournals.ir/article 525449_7a20e067b81fcfe12a320318fc959b2a.pdf

- Abdullah, H. M. (2012). The Effect of a Suggested Program for Teaching Novel Based on Language Decision Making Approach on Developing the 
First Year Secondary School Students' Critical Reading Skills, and its Achievement of the Standards Document.

- Abednia, A., \& Izadinia, M. (2013). Critical pedagogy in ELT classroom: Exploring contributions of critical literacy to learners' critical consciousness. Language Awareness, 22(4), 338-352. https://doi.10.1080/09658416.2012.733400

- Anstey, M., \& Bull, G. (2006). Teaching and Learning Multiliteracies. Newark, NJ: International Reading Association Retrieved 21 February 2021 from

https://www.scirp.org/\%28S\%28351jmbntvnsjt1aadkposzje\%29\%29/ref erence/referencespapers.aspx? referenceid $=2614714$

- Brown, K. (1999). Developing critical literacy. Sydney, Australia: National Centre for English Language Teaching and Research.

- Callison, D. (2006). Critical literacy and inquiry. Educators' Spotlight Digest, 1(3). Retrieved 21 July 2020 from http://www.informationliteracy.org/users_data/admin/Volume1_Issue3_G uest_writer.pdf

- Chaffee, John. (2000). Thinking Critically. Sixth Edition. New York: Houghton Mifflin Company.

- Cho, H. (2015). "I love this approach, but find it difficult to jump in with two feet!" Teachers' perceived challenges of employing critical literacy. English Language Teaching, 8(6), 1916-4750. https://doi.org/10.5539/elt.v8n6p69 
- Dal, S. (2012). İlköğretim 5. sınıf Türkçe dersinde eleştirel okuryazarlık uygulamaları: Bir eylem araştırması (Unpublished PhD Thesis). Anadolu Üniversitesi Eğitim Bilimleri Enstitüsü, Eskişehir.

- Dionne, A. M. (2010). Developing critical literacy skills. Ontario: Research into Practice. EFL Learning. Cairo: Institute of Educational Studies.

- Estern Kentuky University (EKU) Critical Reading Rubric https://qep.eku.edu/sites/qep.eku.edu/files/files/EKU_critical_reading_ru bric.pdf

- Duran, E., \& Yalçintaş, E. (2014). Review of The Critical Reading Education in The Primary Schools. Uşak: Elsevier.

- Escudero, M. D. (2011). Teaching and Learning Critical Reading with Transnational Texts at a Mexican University: An Emergentist Case Study. ProQuest LLC.

- Facione, P. A. (2015). Critical thinking: What it is and why it counts (Sixth edition). California: Measurment Reason LCC and Insight Assessment.

- Fajardo, M. F. (2015). A review of critical literacy beliefs and practices of English language learners and teachers. University of Sydney Papers in TESOL, 10, 29-56.

- Gurr, Tony. (2012). Emotional Literacy for Educators - the 12-step programme!" Allthingslearning. Web. 21 Jun 2012. http://allthingslearning.files.wordpress.com/2012/03/21c-skills-critlit.png>

- Halpern, D. F. (1997). Critical thinking across the curriculum: A brief edition of thought and knowledge. New York, US: Lawrence Erlbaum Associates. P.5 
- Haromi, F. A (2014). Teaching Through Appraisal.Developing Critical Reading in Iranian EFL Learners Procedia.Social and Behavioral Sciences, 98:127-136

- Hazaea, A. N., \& Alzubi, A. A. (2017). Effects of CDA instruction on EFL analytical reading practices. Novitas-ROYAL (Research on Youth and Language), 11(2), 88-101

- Highered. (2010). Critical Thinking Reading Chapter available online at http://www. mcgraw- hill.com/ critical/ thinking/reading /chapter.doc

- Huh, S. (2016). Instructional model of critical literacy in an EFL context: Balancing conventional and critical literacy. Critical Inquiry in Language Studies, 13(3), 210-235. https://doi: 10.1080/ 15427587. 2016.1154445

- Huijie, L. (2010). Developing a hierarchical framework of critical reading proficiency. Chinese Journal Applied linguistics,33:40-54.

- İçmez, S. (2009); "English Critical reading lessons and motivation for English Language Teaching Preparatory class students" Theory and Practice in Education, 5(2), 123-147.

- Janks, H. (2013). Identity and diversity. In H. Janks, K. Dixon, A. Ferreira, S. (Eds).

- Jeong, M (.2012). Developing Critical Literacy through English Newspaper Articles for High-Intermediate EFL Students in Korea. Submitted in Partial Fulfillment of the Requirements for the Degree of Master of Arts in TESOL University of Wisconsin-River Falls 2012. Retrived 15 January 2021 from https://docplayer.net/36619323- 


\section{Developing EFL student's Critical Reading Skills Dr. AL-Shaimaa Abdullah}

Developing-critical-literacy-through-english-newspaper-articles-forhigh-intermediate-efl-students-in-korea.html

- Kaur, S. (2013). Critical Literacy Practices of English Major in a Tertiary Institution. Journal of Language Studies, 13(2), 21-35.

- Ko, M, Y. (2013). Acase study of an EFL teacher's critical literacy teaching in a reading class in Taiwan. Languge Teaching Research,17(1)91-108, DOL:1177/13621688124553

- Kress, Gunther. (2003). Literacy in The New Media Age. London: Routledge. Kurland, Dan. (2011). How the Language Really Works. Reading and Writing Ideas As Well As Words Available on line http://www.criticalreading.com /criticalreading. htm.

- Kurland, Dan. (2011). How the Language Really Works. Reading and Writing Ideas As Well As Words Available on line http://www. criticalreading.com/criticalreading.htm

- Kurt-Taşpınar, H., \& Çubukçu, F. (2020). The impact of critical literacy instruction on adult EFL learners' reading comprehension. Language Teaching and Educational Research (LATER), 3(1), 34-55. https://doi.org/10.35207/later.736070

- Kustini, Siti. (2010). Engaging Critical Thinking in The Teaching of Reading. Unpublished thesis at Indonesia University of Education Bandung

- Longview Community College, Lee's Summit, Missouri. (2000). What Is Critical Thinking? Strategies for Success. 12 April 2004. In Taprizi, N. (2011) Critical Thinking and Critical Reading: Issues and Implications. PhD - Islamic Azad University - Roudehen Branch. Retrieved 20 
February 2021 from https://citeseerx.ist.psu.edu/viewdoc/ download? doi=10.1.1.454.9891\&rep=rep1\&type=pdf

- Mclaughlin, Maureen and Glenn L. Devoogd. Critical Literacy: Enhancing Students' Comprehension of Text. New York: Scholastic Inc, 2004. Print

- Nam, J. (2013). Exploring the challenges of helping students develop critical responses to ESL reading textbooks. ProQuest LLC.

- Oxford, R. L. (2001). Language learning styles and strategies. In Teaching English as A Second or Foreign Language. Boston: Heinle \& Heinle Press.

- Pesarchick, M. R. (2018). Critical Literacy Practices in an Elementary School Classroom: A Study of Teacher Learning. ProQuest.

- Peterson`s (2008). Master Critical Thinking for the SAT. Peterson`s. P.124)

- Potur, Ö. (2014). Ortaokul Türkçe derslerinde eleştirel okuryazarlık eğitimi (Unpublished PhD Thesis). Çanakkale Onsekiz Mart Üniversitesi Eğitim Bilimleri Enstitüsü, Çanakkale. Huang, 2011 Retrieved 20 February 2021 from https://citeseerx.ist.psu.edu/viewdoc/download?doi= 0.1.1.454. 9891\&rep=rep1\&type $=$ pdf

- Ramirez-Nava, C. M. (2013). Exploring critical literacy through teachers' professional learning. Curriculum and Instruction. Boise state: Boise state university.

- Bedford/St. Martin's, (1999). A Catalog of Critical Reading Strategies" in Rise B. Axelrod and Charles R. Cooper, Reading Critically, Writing Well: A Reader and Guide, Fifth Ed., New York: .1999 
- Reichenbach, R. Bruce. (2001). Introduction to Critical Thinking. New York: The McGraw-Hill Companies, Inc. Sary, F.M. (2006) Teacher's Strategies in Teaching English as a Foreign Language to Primary School Studies. Unpublished thesis at Indonesia University of Education Bandung.

- Roberge, G. D. (2013). Promoting critical literacy across the curriculum and fostering safer learning environments. What Works? Research into Practice, 48, 1-4.

- Schooten, E. V., \& Glopper, D. K. (2003). The development of literary response in secondary education. Poetics, 31(3), 155-187. http://www.criticalthinking.org/university/univclass/Defining.htm

- Wallace, Catherine. (2003). Critical Reading in Language Education. London: Palgrave. Macmillan.

- Weissman, R. (2018). South Calorina preschool teachers perceptionsand implementing critical literacy in the preschool classroom. ProQuest.

- Yildirim, S., \& Soylemez, Y. (2018). The Effect of Performing Reading Activities with Critical Reading Questions on Critical Thinking and Reading Skills. Asian Journal of Education and Training, 4(4), 326-335.

- Zintz, M. V., and Z. R. Maggart. (1984). The Reading Process, the Teacher and the Learner. In Taprizi, N.(2011) Critical Thinking and Critical Reading: Issues and Implications. PhD - Islamic Azad University - Roudehen Branch. Retrieved 20 February 2021 from https://citeseerx.ist.psu.edu/viewdoc/download?doi=10.1.1.454.9891\&r $\underline{\text { ep}=\text { rep } 1 \& \text { type }=\text { pdf }}$ 